\title{
PENGARUH SUMBER DAYA MANUSIA, SISTEM PENGENDALIAN INTERN PEMERINTAH DAN AUDIT KEUANGAN DAERAH TERHADAP KUALITAS LAPORAN KEUANGAN
}

\author{
Agustiawan', Annie Mustika Putri'2, Yoni Saputra ${ }^{3}$ \\ Fakultas Ekonomi dan Bisnis Universitas Muhammadiyah Riau \\ agustiawan@umri.ac.id
}

\begin{abstract}
The purpose of this study is to examine the effect of human resources, the government's internal control system and regional financial audits towards the quality of financial statements. The population in this study was all employees in the Office of the Regional Financial and Asset Management Agency (BPKAD) Riau Province whilst the sample was 116 respondents. The sampling method in this research is census sampling. The data used were primary data, which was completely done by using survey methods with questionnaires and the processing method used was multiple linear regression. The result of this study conveys that the variables of human resources, internal government control systems and regional financial audits affect the quality of financial statements.
\end{abstract}

Keywords: Human Resources, Government Internal Control Systems, Regional Financial Audits And Financial Statement Quality

\section{PENDAHULUAN}

Pelaporan keuangan pemerintah merupakan komponen penting dalam mewujudkan akuntabilitas keuangan sektor public. Perkembangan pencataan laporan keuangan dan penerapannya di organisasi sektor publik dalam hal ini pemerintah dari waktu kewaktu semangkin mengarah kepada perbaikan. Implikasi yang timbul terhadap manajemen dalam pelaksanaan akuntabilitas public pada pada instansi pemerintah dalam memberikan informasi kepada publik, salah satunya adalah informasi dalam pelaporan keuangan. Dengan adanya pelaporan keuangan, maka akan membantu memenuhi kebutuhan para pengguna laporan keuangan serta juga memenuhi kewajiban pemerintah agar menjadi lebih akuntabel secara public. Fenomena entitas sektor publik di Indonesia saat ini masih banyak pelaporan keuangan yang belum menyajikan informasi sesuai dengan peraturan dan masih banyak penyimpangan dalam pelaporan keuangan terutama pelaporan keuangan pemerintah daerah (Alaihi, 2017). Agustiawan (2019) Mengungkapkan bahwa Laporan pemerintah terhadap kinerja organisai pemerintah masih sebatas memenuhi tanggungjawab organisasi pemerintah, belum memaksimalkan mengapa laporan tersebut dibuat.
Dari hasil pemeriksaan BPK RI Perwakilan Provinsi Riau atas Laporan Hasil Pemeriksaan (LHP) masih terdapat alokasi anggaran untuk kegiatan yang bukan merupakan kewenangan Pemerintah Provinsi

Riau seperti dana perimbangan terdiri dari dana bagi hasil pajak dan bukan pajak, dana alokasi umum dan dana alokasi khusus, proses penganggaran pemerintah provinsi riau yang tidak sesuai dan kelebihan dalam pembayaran anggaran untuk perjalan dinas atau proyek pengadaan pada Satuan Kerja Perangkat Daerah (SKPD) Provinsi Riau. Hal ini dapat diindikasi bahwa pemerintah masih belum memaksimalkan kinerjanya dalam pelaporan keuangan pemerintah untuk menuju kualitas laporan keuangan yang akuntabel.

Ada banyak faktor yang mempengaruhi kualitas laporan keuangan, Antara lain sumber daya manusia, sistem pengendalian internal pemerintah dan audit keuangan. Peneliti mengungkapkan tiga faktor ini karena cakupan dalam penelitian ini hanya membahas tiga faktor saja dengan alasan sebagai berikut. Sumber Daya Manusia adalah faktor yang sangat penting untuk organisasi, dan juga merupakan aset organisasi baik sektor swasta maupun pemerintah. Guna mewujudkan pelaporan yang akuntabel diharapkan sumber daya manusia memiliki kontribusi terhdapa pembutan kualitas 
laporan keuangan. Dengan sumber daya manusia yang berkualitas akan dapat menghemat waktu pembuatan laporan keuangan, hal ini disebabkan karena sumber daya manusia tersebut telah mengetahui dan memahami apa yang akan dikerjakan sehingga penyajian laporan keuangan dapat selesai tepat waktu (Mardiasmo, 2009).

Selain itu, juga diharapkan adanya sistem pengendalian intern pemerintah dalam meningkatkan kualitas penyusunan laporan keuangan yang lebh baik lagi sehingga laporan keuangan yang dibuat oleh Pemerintah Pusat ataupun Pemerintah Daerah dapat memperoleh opini yang semakin baik. Karena dengan meningkatnya opini yang diberikan oleh Badan Pemeriksa Keuangan (BPK) atas suatu laporan keuangan, berarti laporan tersebut dapat dipercaya sebagai alat pengambilan keputusan oleh para pemangku kepentingan (stakeholders). Kemudian sistem pengendalian intern pemerintah yang baik dapat mencegah pelaksanaan kegiatan yang tidak sesuai dengan ketentuan yang berlaku sehingga dapat memperoleh efisiensi, efektivitas, dan mencegah terjadinya kerugian keuangan negara (Purba, 2018).

Sesuai dengan isi Undang-Undang Nomor 15 Tahun 2004 menyatakan bahwa Pemeriksaan Keuangan Daerah adalah proses identifikasi masalah, analisis, dan evaluasi yang dilakukan secara independen, obyektif, dan profesional berdasarkan standar pemeriksaan, untuk menilai kebenaran, kecermatan, kredibilitas, dan keandalan informasi mengenai pengelolaan dan tanggung jawab Keuangan Negara. Untuk meyakinkan pengelolaan dan pertanggungjawaban keuangan daerah berjalan sesuai kriteria yang ditetapkan, perlu dilakukan oleh suatu badan pemeriksa yang profesional, efektif, efisien, dan modern (Nazaruddin dan Syahrial, 2017).

Permasalahan terkait kualitas laporan keuangan pemerintah selalu terjadi dan perkembangan penelitian terlait area kualitas laporan keuangan sampai saat ini juga masih diminat oleh para peneliti dan memiliki hasil yang berbeda-beda, seperti yang dilakukan oleh Triyanti (2017) mengatakan sumber daya manusia berpengaruh terhadap kualitas laporan keuangan, sedangkan Syahadatina. at.al (2016) mengatakan sumber daya manusia tidak berpengaruh terhadap kualitas laporan keuangan berbeda. Syahadatina. at.al (2016) mengatakan sistem pengendalian intern pemerintah berpengaruh terhadap kualitas laporan keuangan, namun berbeda dengan Purba (2018) yang mengatakan bahwa sistem pengendalian intern pemerintah tidak berpengaruh terhadap kualitas laporan keuangan.

Berdasarkan permasalahan yang dipaparkan dan masih adanya ketidak konsistenan hasil penelitisn sejenis makan menari rumusan masalah sebagai berikut: 1.Apakah sumber daya manusia berpengaruh terhadap kualitas laporan keuangan?. 2.Apakah sistem pengendalian intern pemerintah berpengaruh terhadap kualitas laporan keuangan?. 3.Apakah audit keuangan daerah berpengaruh terhadap kualitas laporan keuangan?

\section{KAJIAN TEORI DAN PENGEMBANGAN HIPOTESIS}

Konsep senjangan anggaran yang berakhir pada laporan keuangan pemerintah yang berkualitas dapat dimulai pada pendekatan teori keagenan. Agency theory adalah pendesainan kontrak yang tepat untuk menyelaraskan kepentingan principal dan agent dalam hal terjadi konflik kepentingan. Hal ini dapat terjadi ketika adanya tututan atau desakan dari pengguna laporan keuangan dalam hal ini masyarakat pada umumnya untuk mencapai keberhasilan kualita laporan keuangan yang akuntabel maka pemerintah sebagai egent harus memperioritaskan pepentingan keselurahan masyarakat.

Hubungan keagenan merupakan sebuah kontrak antara principal dengan agent, dengan melihat pendelegasian beberapa wewenang pengambilan keputusan kepada agent. Sebagai agent, pemerintah secara moral memiliki tanggung jawab untuk memaksimalkan kepercayaan yang diberikan oleh (principal) yakni masyarakat. Diliahat dari sejarah pemerintahan Indonesia. Negara Indonesia merupakan negara yang demokrasi memiliki hubungan keagenan antara masyarakat dengan pemerintah atau hubungan antara pemerintah daerah dengan pemerintah pusat. Pemerintah pusat memberikan wewenang terhadap pemerintah daerah pemerintah daerah juga harus mempertanggung jawabkan tugasnya terhadap pemerintah pusat sesuai dengan 
peraturan otonomi daerah. Akhirnya pemerintah daerah harus mempertanggung jawabkan realisasi anggaran terhadap pemerintah pusat (Halim, 2012). Selain hubungan pemerintah pusat dan daerah juga ada hubungan antara legislative dan eksekutif, eksekutif adalah agen sedangkan legislative adalah principal. Legislator adalah pihak yang mendelegasian wewenang kepada agen seperti pemerintah atau panitia di legislative untuk membuat kebijakan baru. Agen disini membuat usulan kebijakan dan nantinya usulan agen tersebut diterima atau di tolak (Halim, 2012).

\section{Kualitas Laporan Keuangan}

Menurut Peraturan Menteri Dalam Negeri Nomor 13 Tahun 2006, laporan keuangan daerah disusun untuk menyediakan informasi yang relevan mengenai posisi keuangan dan seluruh transaksi yang dilakukan oleh pemerintah daerah selama satu periode pelaporan. Dimana tujuan laporan keuangan untuk menyediakan informasi yang terkait dengan posisi keuangan, kinerja, serta perubahan posisi keuangan suatu perusahaan yang bermanfaat bagi pemakai dalam pengambilan keputusan. Dengan demikian, suatu laporan keuangan dapat dikatakan sebagai data dan juga informasi. Secara spesifik dapat disimpulkan bahwa tujuan pelaporan keuangan adalah untuk menyajikan informasi yang berguna untuk pengambilan keputusan (IAI, 2016).

\section{Sumber Daya Manusia}

Sumber daya manusia memiliki peran yang penting dalam menentukan kemajuan suatu organisasi swasta maupun pemerintah telbih lagi dengan kondisi era revolusi 4.0. Jika sumber daya manusia tidak berkompenten dibidangkan maka akan menunggu waktu ditukar dengan mesin. Jika dilihat dari keterjadian faktor utama penentu adalah kwalitas dari sumber daya tersebut bukan bukanlah kuantitas sumber daya. Sumber daya manusia merupakan asset organisasi yang perlu dijaga untuk keberlangsungan organisasi. Sumber daya manusia adalah faktor penting demi terciptanya laporan keuangan yang berkualitas. Keberhasilan suatu entitas bukan hanya dipengaruhi oleh sumber daya manusia yang dimilikinya melainkan kompetensi sumber daya manusia yang dimilikinya (Triyanti, 2017).

\section{Sistem Pengendalian Internal Pemerintah}

Menurut Peraturan Pemerintah

Nomor 60 Tahun 2008 tentang Sistem Pengendalian Intern Pemerintah adalah: "Proses yang integral pada tindakan dan kegiatan yang dilakukan secara terus menerus oleh pimpinan dan seluruh pegawai untuk memberikan keyakinan memadai atas tercapainya tujuan organisasi melalui kegiatan yang efektif dan efisien, keandalan pelaporan keuangan, pengamanan aset negara, dan ketaatan terhadap peraturan perundang-undangan". Sistem Pengendalian Intern Pemerintah (SPIP) dilaksanakan oleh Badan Pengawasan Keuangan dan Pembangunan (BPKP) dan Inspektorat melalui Aparat Pengawasan Intern Pemerintah/ Sedangkan Sistem Pengendalian Eksternal pemerintah dilaksanakan oleh Badan Pemeriksa Keuangan (BPK), DPR/DPRD, Kepolisian, Kejaksaan, Komisi Pemberantasan Korupsi dan lembaga peradilan lainnya. Dengan adanya SPIP tersebut diharapkan dapat meminimalisir terjadinya tindakan yang dapat merugikan Negara.

\section{Audit Keuangan Daerah}

Audit Keuangan Daerah merupakan pengawasan manajerial yang fungsinya mengukur dan mengevaluasi sistem pengendalian dengan tujuan membantu semua anggota manajemen dalam mengelola secara efektif pertanggungjawabannya dengan menyediakan analisis, penilaian, rekomendasi, dan komentar-komentar yang berhubungan dengan kegiatan-kegiatan yang ditelaah. Tujuan audit intern keuangan daerah adalah meneliti dan menilai apakah pelaksanaan daripada pengendalian intern di bidang akuntansi dan operasi cukup dan memenuhi syarat. Menilai disini dimaksudkan menilai apakah kebijakan, rencana dan prosedur yang telah ditentukan betul-betul ditaati, menilai apakah aktiva perusahaan aman dari kehilangan atau kerusakan dan penyelewengan, menilai kecermatan data akuntansi dan data lain dalam organisasi perusahaan, dan menilai mutu atau pelaksanaan daripada tugas-tugas yang diberikan kepada masing-masing manajemen. 


\section{Pengaruh Sumber Daya Manusia Terhadap Kualitas Laporan Keuangan}

Sumber daya manusia yang memiliki kualitas yang tinggi akan dapat menunjang kinerja suatu organisasi sehingga dapat mengalami kemajuan. Sumber daya manusia dapat diukur melalui pengetahuan, keterampilan dan perilaku. Ketiga hal tersebut yang harus dimiliki dan diperhatikan oleh setiap orang untuk menunjang keberhasilan dalam melaksankan tugas. Semakin baik sumber daya manusia di sebuah perusahaan, maka semakin baik kualitas laporan keuangan yang dihasilkan. Laporan keuangan sebagai output memerlukan sumber daya manusia yang mengimplementasikan, untuk itu diperlukan sumber daya manusia yang kompeten dan memiliki pemahaman yang baik tentang pengelolaan keuangan pemerintah daerah, sehingga akan lebih mudah dalam melaksanakan tugas dan tanggung jawab yang diberikan.

Sumber daya manusia yang kompeten tersebut tentunya harus memiliki bekal pendidikan, pelatihan dan pengalaman (Triyanti, 2017). Hal ini seperti di hasil penelitian dari Triyanti (2017) dan Kuncoro (2017) bahwa sumber daya manusia berpengaruh terhadap kualitas laporan keuangan. Teori keagenan juga mengungkapkan hal yang sama, dimana adanya sumber daya manusia yang baik akan memudahkan agent dalam mengkomunikasikan pekerjaan dengan principal sehingga tidak terdapat kesalahpahaman. Berdasarkan penjelasan di atas, maka dapat dirumuskan hipotesis sebagai berikut:

H1: Sumber Daya Manusia berpengaruh terhadap Kualitas Laporan Keuangan.

\section{Pengaruh Sistem Pengendalian Intern Pemerintah terhadap Kualitas Laporan Keuangan}

Sistem pengendalian intern sebagaimana disebutkan sebelumnya terdiri atas lima dimensi, yaitu lingkungan pengendalian, penilaian risiko, kegiatan pengendalian, informasi dan komunikasi, serta pengawasan. Lingkungan pengendalian merupakan dasar bagi keseluruhan sistem pengendalian intern, dimana lingkungan pengendalian yang buruk memberikan kontribusi yang signifikan dalam kegagalan efektifitas unsur sistem pengendalian intern lainnya (COSO, 2013). Pengendalian internal dapat mengawasi dalam jalannya manajemen sebuah perusahaan, dapat dikatakan bahwa semakin baik sistem pengendalian intern di sebuah perusahaan, maka semakin baik kualitas laporan keuangan yang dihasilkan. Hal ini seperti di hasil penelitian dari Triyanti (2017) dan Purba (2018) bahwa sistem pengendalian intern berpengaruh terhadap kualitas laporan keuangan. Teori keagenan juga mengungkapkan hal yang sama, dimana sistem pengendalian internal memudahkan principal dalam melakukan pengawasan terhadap apa yang dilakukan agen terkait pelaporan keuangan yang berkualitas. Berdasarkan penjelasan di atas, maka dapat dirumuskan hipotesis sebagai berikut:

H2: Sistem Pengendalian Intern berpengaruh terhadap Kualitas Laporan Keuangan.

\section{Pengaruh Audit Keuangan Daerah Terhadap Kualitas Laporan Keuangan}

Audit Keuangan Daerah merupakan suatu fungsi penilaian yang bebas dalam suatu organisasi guna menelaah atau mempelajari dan menilai kegiatan-kegiatan perusahaan untuk memberikan saran kepada manajemen. Tujuan audit intern keuangan daerah adalah meneliti dan menilai apakah pelaksanaan daripada sistem pengendalian intern di bidang akuntansi dan operasi cukup dan memenuhi syarat. Menilai disini dimaksudkan menilai apakah kebijakan, rencana dan prosedur yang telah ditentukan betul-betul ditaati, menilai apakah aktiva perusahaan aman dari kehilangan atau kerusakan dan penyelewengan, menilai kecermatan data akuntansi dan data lain dalam organisasi perusahaan, dan menilai mutu atau pelaksanaan daripada tugas-tugas yang diberikan kepada masing-masing manajemen. Jika audit keuangan daerah berjalan dengan baik, maka kualitas laporan keuangan pun akan baik. Hal ini seperti di hasil penelitian dari Sukmandiansyah (2015) bahwa Audit Keuangan Daerah berpengaruh terhadap kualitas laporan keuangan. Teori keagenan juga mengungkapkan hal yang sama, dimana dengan adanya audit keuangan daerah, kesalahan-kesalahan dan penyimpanganpenyimpangan akan dengan mudah terdeteksi 
sehingga akan menghasilkan laporan keuangan yang dapat dipertanggungjawabkan. Berdasarkan penjelasan di atas, maka dapat dirumuskan hipotesis sebagai berikut: H3: Audit Keuangan Daerah berpengaruh Terhadap Kualitas Laporan Keuangan.

\section{MODEL PENELITIAN}

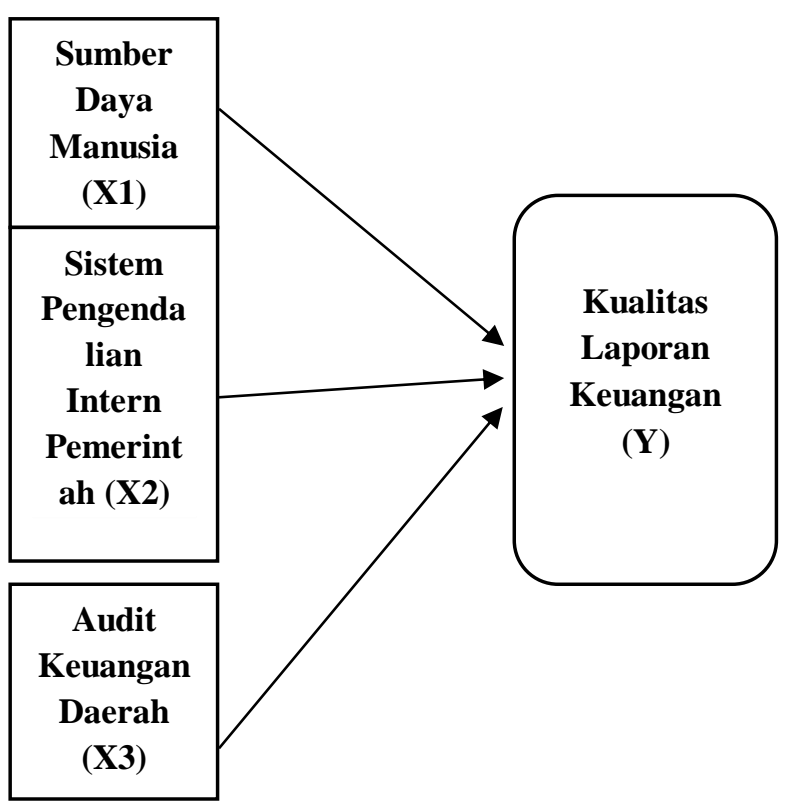

\section{Gambar Model Penelittian}

\section{METODE PENELITIAN}

Penelitian ini merupakan penelitian kuantitatif dengan survey. Dalam penelitian survey dilakukan dengan menyebarkan daftar pernyataan berupa kuisioner yang akan disebarkan kepada responden. Lokasi Penelitian pada penelitian ini adalah di kantor Badan Pengelolaan Keuangan dan Aset Daerah (BPKAD) Provinsi Riau yang terletak di Jalan Cut Nyak Dien. Peneliti memilih kantor BPKAD Provinsi Riau sebagai objek penelitian karena pegawai kantor BPKAD Provinsi Riau yang melaksanakan tugas dan fungsi sebagai pengelola keuangan di Provinsi Riau. Data yang digunakan adalah data primer. Populasi dalam penelitian ini Populasi dalam penelitian ini adalah Pegawai Negeri Sipil (PNS) di lingkungan Badan Pengelola Keuangan dan Aset Daerah (BPKAD) Provinsi Riau yaitu sebanyak 116 orang. Sampel dalam penelitian ini adalah Pegawai Negeri Sipil (PNS) di lingkungan Badan Pengelola Keuangan dan
Aset Daerah (BPKAD) Provinsi Riau yaitu sebanyak 116 orang.

\section{Defenisi Operasional Variabel}

Indikator kualitas laporan keuangan pemerintah daerah mengacu pada karakteristik kualitatif laporan keuangan menurut Peraturan Pemerintah Nomor 71 Tahun 2010 tentang Standar Akuntansi Pemerintah yang terdiri dari 16 pernyataan diadopsi dari Triyanti (2017). Variabel ini diukur dengan menggunakan skala likert dengan skor yang digunakan yaitu $1 \mathrm{~s} / \mathrm{d} 5$ yaitu (1) sangat tidak setuju (2) tidak setuju (3) kurang setuju (4) setuju (5) sangat setuju. Menurut Undang-Undang Nomor 7 Tahun 2013 mengenai Pedoman Penyusunan Standar Kompetensi Manajerial Pegawai Negeri Sipil yang terdiri dari 15 pernyataan diadopsi dari Triyanti (2017). Variabel ini diukur dengan menggunakan skala likert dengan skor yang digunakan yaitu $1 \mathrm{~s} / \mathrm{d} 5$ yaitu (1) sangat tidak setuju (2) tidak setuju (3) kurang setuju (4) setuju (5) sangat setuju.

Variabel keefektifan pengendalian internal pemerintah yar * +^rdiri dari 21 pernyataan diadopsi da yanti (2017), hasil pengembangan uaı Peraturan Pemerintah No.60 Tahun 2008 tentang Sistem Pengendalian Intern Pemerintah. Lima (5) indikator komponen pengendalian internal adalah lingkungan pengendalian, penilaian risiko, kegiatan pengendalian, informasi dan komunikasi, serta pemantauan. Variabel ini diukur dengan menggunakan skala likert dengan skor yang digunakan yaitu $1 \mathrm{~s} / \mathrm{d} 5$ yaitu (1) sangat tidak setuju (2) tidak setuju (3) kurang setuju (4) setuju (5) sangat setuju. Variabel audit keuanga daerah terdiri dari 14 pernyataan diadopsi dari Sukmandiansyah (2015. Variabel ini diukur dengan menggunakan skala likert dengan skor yang digunakan yaitu $1 \mathrm{~s} / \mathrm{d} 5$ yaitu (1) sangat tidak setuju (2) tidak setuju (3) kurang setuju (4) setuju (5) sangat setuju.

Untuk menguji hipotesis dalam penelitian ini menggunakan analisis linier berganda. Alat analisi penelitian ini menggunakan software SPSS (Statistical Product and Service Solution) for Windows ver 25. 


\section{HASIL DAN PEMBAHASAN}

\section{Deskripsi Data Responden}

Responden dalam penelitian ini adalah kantor Badan Pengelolaan Keuangan dan Aset Daerah (BPKAD) Provinsi Riau Peneliti menyerahkan 116 eksemplar kuisioner penelitian dari tanggal 27 Desember 2019 hingga 3 Januari 2020 kepada masing-masing pegawai dengan tanggal pengembalian yang disepakati. Dari $116(100 \%)$ kuisioner yang disebar, 116 (100\%) kuisioner diterima kembali, 0 (0\%) tidak dikembalikan kepada peneliti, dengan kata lain penelitian ini mempunyai response rate sebesar $100 \%$, sehingga data yang dapat digunakan untuk di analisis sebanyak 116 kuisioner. Rincian mengenai tingkat pengembalian kuisioner disajikan dalam tabel berikut:

Tabel Daftar Pengiriman dan Pengembalian Kuisioner

\begin{tabular}{|l|l|l|}
\hline Keterangan & Jumlah & $\begin{array}{l}\text { Presentase } \\
(\%)\end{array}$ \\
\hline $\begin{array}{l}\text { Kuisioner yang } \\
\text { disebar }\end{array}$ & 116 & 100 \\
\hline $\begin{array}{l}\text { Kuisioner yang } \\
\text { kembali }\end{array}$ & 116 & 100 \\
\hline $\begin{array}{l}\text { Kuisioner yang } \\
\text { tidak kembali }\end{array}$ & 0 & 0 \\
\hline $\begin{array}{l}\text { Kuisioner yang } \\
\text { tidak dapat } \\
\text { dianalisis }\end{array}$ & 18 & 15,52 \\
\hline $\begin{array}{l}\text { Kuisioner yang } \\
\text { dapat } \\
\text { dianalisis }\end{array}$ & 98 & 84,48 \\
\hline $\begin{array}{l}\text { Jumlah seluruh } \\
\text { kuisioner }\end{array}$ & 116 & 100 \\
\hline \multicolumn{2}{|c|}{ Sumber: Data Olahan Peneliti } \\
\hline
\end{tabular}

\section{Data Responden}

\section{Tabel Demografi Responden}

\begin{tabular}{|l|l|l|}
\hline Umur & Frekuensi & $\begin{array}{l}\text { Persentase } \\
(\%)\end{array}$ \\
\hline $20-35$ & 21 & 21,43 \\
\hline $35-50$ & 77 & 78,57 \\
\hline Total & 98 & 100 \\
\hline $\begin{array}{l}\text { Jenis } \\
\text { Kelamin }\end{array}$ & Frekuensi & $\begin{array}{l}\text { Persentase } \\
(\%)\end{array}$ \\
\hline Laki-laki & 45 & $45,92 \%$ \\
\hline Perempuan & 53 & $54,08 \%$ \\
\hline Total & 98 & $100 \%$ \\
\hline Jabatan & Frekuensi & Persentase \\
\hline
\end{tabular}

\begin{tabular}{|l|l|l|}
\hline & & $(\%)$ \\
\hline Kabid & 3 & 3,06 \\
\hline Kasubid & 5 & 5,10 \\
\hline Staf & 90 & 91,84 \\
\hline Total & 98 & 100 \\
\hline $\begin{array}{l}\text { Pendidikan } \\
\text { Terakhir }\end{array}$ & Frekuensi & $\begin{array}{l}\text { Persentase } \\
(\%)\end{array}$ \\
\hline Diploma & 21 & 21,42 \\
\hline S1 & 52 & 53,06 \\
\hline S2 & 25 & 25,52 \\
\hline Total & 98 & 100 \\
\hline $\begin{array}{l}\text { Lama } \\
\text { Bekerja }\end{array}$ & Frekuensi & $\begin{array}{l}\text { Persentase } \\
(\%)\end{array}$ \\
\hline $1-5$ tahun & 5 & 5,10 \\
\hline 5-10 tahun & 28 & 28,57 \\
\hline$>10$ tahun & 65 & 66,33 \\
\hline Total & 98 & 100 \\
\hline \multicolumn{2}{|c|}{ Sumber: Data 0lahan Peneliti } \\
\hline
\end{tabular}

Berdasarkan tabel di atas, menunjukkan jumlah responden yang paling banyak adalah responden yang berusia 35-50 tahun yaitu 77 orang atau $78,57 \%$ dibandingkan responden yangg berusia 20-35 tahun yaitu 21 orang atau $21,43 \%$. Hal ini mendukung sumber daya manusia yang baik dalam menyusun laporan keuangan, sehingga kualitas laporan keuangan menjadi lebih baik. Jumlah responden laki laki sebanyak 45 orang atau $45,92 \%$ lebih kecil dibandingkan jumlah responden perempuan yang berjumlah 53 orang atau $54,08 \%$.

Jabatan responden yang mengisi kuisioner lebih banyak staf yaitu sebanyak 90 orang atau 91,84\% dibandingkan kasubid (kepala sub bidang) sebanyak 5 orang atau $5,10 \%$ dan Kabid sebanyak 3,06\%. Hal ini menunjukkan bahwa staff memiliki andil lebih banyak dalam menyusun laporan keuangan. Pendidikan responden yang mengisi kuisioner lebih banyak bergelar S1 yaitu 52 responden. Sedangkan selanjutnya beruturut turut S2 sebanyak 25 responden, dan Diploma sebanyak 21 responden. Hal ini menunjukkan bahwa sumber daya manusia yang dimiliki sudah cukup berkompeten, di lihat dari jenjang pendidkan terakhirnya. kuisioner paling banyak diisi oleh responden dengan lama bekerja >10 tahun yaitu sebanyak 65 orang atau $66,33 \%$ dibandingkan dengan lama bekerja 5-10 tahun sebanyak 28 orang atau $28,57 \%$ dan dengan lama bekerja 1-5 tahun sebanyak 5 orang atau 5,10\%. 


\section{Statistik Deskriptif}

Statistik dalam penelitian ini merujuk pada rata-rata (mean) dan simpangan baku (standar deviation) dari seluruh variabel dalam penelitian ini yaitu Sumber Daya Manusia (X1), Sistem Pengendalian Internal Pemerintah (X2), Audit Keuangan Daerah (X3) dan Kualitas Laporan Keuangan (Y) sebagaimana ditunjukkan pada tabel di bawah ini:

Tabel Statistik Deskriptif

\begin{tabular}{|l|l|l|l|l|l|}
\hline Keterangan & $\mathrm{N}$ & $\begin{array}{l}\text { Minim } \\
\text { um }\end{array}$ & $\begin{array}{l}\text { Max } \\
\text { imu } \\
\mathrm{m}\end{array}$ & $\begin{array}{l}\text { Mea } \\
\mathrm{n}\end{array}$ & $\begin{array}{l}\text { Std } \\
\text { Deviati } \\
\text { on }\end{array}$ \\
\hline $\begin{array}{l}\text { Sumber Daya } \\
\text { Manusia }\end{array}$ & 98 & 39 & 75 & $\begin{array}{l}57.0 \\
3\end{array}$ & 7.709 \\
\hline $\begin{array}{l}\text { Sistem } \\
\text { Pengendalian } \\
\text { Internal }\end{array}$ & 98 & 52 & 105 & $\begin{array}{l}81.1 \\
6\end{array}$ & 13.448 \\
\hline $\begin{array}{l}\text { Audit } \\
\text { Keuangan } \\
\text { Daerah }\end{array}$ & 98 & 28 & 70 & $\begin{array}{l}53.6 \\
1\end{array}$ & 6.868 \\
\hline $\begin{array}{l}\text { Kualitas } \\
\text { Laporan } \\
\text { Keuangan }\end{array}$ & 98 & 45 & 80 & 61.1 & 7.434 \\
\hline $\begin{array}{l}\text { Valid N } \\
\text { (listwise) }\end{array}$ & 98 & & 3 & \\
\hline
\end{tabular}

Berdasarkan hasil perhitungan dari tabel di atas dapat diketahui bahwa $n$ atau jumlah data responden yaitu 98 responden yang berasal dari kantor BPKAD Provinsi Riau. Masing-masing variabel akan dijabarkan sesuai dengan data pada tabel diatas sebagai berikut:

Variabel Sumber Daya Manusia mempunyai nilai mean atau nilai rata-rata sebesar 57.03 dengan standar deviasi atau akar pangkat dari mean sebesar 7.709 yang artinya bahwa nilai mean lebih besar dari standar deviasi, sehingga mengindikasi bahwa hasil yang cukup baik. Variabel Sistem Pengendalian Internal mempunyai nilai mean atau nilai rata-rata sebesar 81.16 dengan standar deviasi atau akar pangkat dari mean sebesar 13.448 yang artinya bahwa nilai mean lebih besar dari standar deviasi, sehingga mengindikasi bahwa hasil yang cukup baik.

Variabel Audit Keuangan Daerah mempunyai nilai mean atau nilai rata-rata sebesar 53.61 dengan standar deviasi atau akar pangkat dari mean sebesar 6.868 yang artinya bahwa nilai mean lebih besar dari standar deviasi, sehingga mengindikasi bahwa hasil yang cukup baik. Variabel Kualitas
Laporan Keuangan mempunyai nilai mean atau nilai rata-rata sebesar 61.13 dengan standar deviasi atau akar pangkat dari mean sebesar 7.434 yang artinya bahwa nilai mean lebih besar dari standar deviasi, sehingga mengindikasi bahwa hasil yang cukup baik.

\section{Uji Validitas Data}

Berdasarkan analisis yang telah dilakukan, maka hasil pengujian validitas dapat ditunjukkan pada tabel sebagai berikut:

\section{Tabel Uji Validitas Data}

\begin{tabular}{|c|c|c|c|c|}
\hline Variabel & Keterangan & $\mathrm{r}$ tabel & $\begin{array}{c}\mathrm{r} \\
\text { hitung }\end{array}$ & Hasil \\
\hline $\mathrm{X} 1$ & $\begin{array}{l}\text { Pernyataan } \\
1\end{array}$ & 0,1986 & 0,792 & Valid \\
\hline $\mathrm{X} 1$ & $\begin{array}{l}\text { Pernyataan } \\
2\end{array}$ & 0,1986 & 0,814 & Valid \\
\hline $\mathrm{X} 1$ & $\begin{array}{l}\text { Pernyataan } \\
3\end{array}$ & 0,1986 & 0,451 & Valid \\
\hline $\mathrm{X} 1$ & $\begin{array}{l}\text { Pernyataan } \\
4\end{array}$ & 0,1986 & 0,604 & Valid \\
\hline $\mathrm{X} 1$ & $\begin{array}{l}\text { Pernyataan } \\
5\end{array}$ & 0,1986 & 0,604 & Valid \\
\hline $\mathrm{X} 1$ & $\begin{array}{l}\text { Pernyataan } \\
6\end{array}$ & 0,1986 & 0,541 & Valid \\
\hline $\mathrm{X} 1$ & $\begin{array}{l}\text { Pernyataan } \\
7\end{array}$ & 0,1986 & 0,659 & Valid \\
\hline $\mathrm{X} 1$ & $\begin{array}{l}\text { Pernyataan } \\
8\end{array}$ & 0,1986 & 0,776 & Valid \\
\hline $\mathrm{X} 1$ & $\begin{array}{l}\text { Pernyataan } \\
9\end{array}$ & 0,1986 & 0,775 & Valid \\
\hline $\mathrm{X} 1$ & $\begin{array}{l}\text { Pernyataan } \\
10\end{array}$ & 0,1986 & 0,792 & Valid \\
\hline $\mathrm{X} 1$ & $\begin{array}{l}\text { Pernyataan } \\
11\end{array}$ & 0,1986 & 0,814 & Valid \\
\hline $\mathrm{X} 1$ & $\begin{array}{l}\text { Pernyataan } \\
12\end{array}$ & 0,1986 & 0,451 & Valid \\
\hline $\mathrm{X} 1$ & $\begin{array}{l}\text { Pernyataan } \\
13\end{array}$ & 0,1986 & 0,604 & Valid \\
\hline $\mathrm{X} 1$ & $\begin{array}{l}\text { Pernyataan } \\
14\end{array}$ & 0,1986 & 0,541 & Valid \\
\hline $\mathrm{X} 2$ & $\begin{array}{l}\text { Pernyataan } \\
1\end{array}$ & 0,1986 & 0,916 & Valid \\
\hline $\mathrm{X} 2$ & $\begin{array}{l}\text { Pernyataan } \\
2\end{array}$ & 0,1986 & 0,921 & Valid \\
\hline $\mathrm{X} 2$ & $\begin{array}{l}\text { Pernyataan } \\
3\end{array}$ & 0,1986 & 0,456 & Valid \\
\hline $\mathrm{X} 2$ & $\begin{array}{l}\text { Pernyataan } \\
4\end{array}$ & 0,1986 & 0,903 & Valid \\
\hline $\mathrm{X} 2$ & $\begin{array}{l}\text { Pernyataan } \\
5\end{array}$ & 0,1986 & 0,869 & Valid \\
\hline $\mathrm{X} 2$ & $\begin{array}{l}\text { Pernyataan } \\
6\end{array}$ & 0,1986 & 0,916 & Valid \\
\hline $\mathrm{X} 2$ & $\begin{array}{l}\text { Pernyataan } \\
7\end{array}$ & 0,1986 & 0,469 & Valid \\
\hline $\mathrm{X} 2$ & $\begin{array}{l}\text { Pernyataan } \\
8\end{array}$ & 0,1986 & 0,919 & Valid \\
\hline $\mathrm{X} 2$ & $\begin{array}{l}\text { Pernyataan } \\
9\end{array}$ & 0,1986 & 0,920 & Valid \\
\hline $\mathrm{X} 2$ & Pernyataan & 0,1986 & 0,919 & Valid \\
\hline
\end{tabular}




\begin{tabular}{|c|c|c|c|c|}
\hline & 10 & & & \\
\hline $\mathrm{X} 2$ & $\begin{array}{l}\text { Pernyataan } \\
11\end{array}$ & 0,1986 & 0,541 & Valid \\
\hline $\mathrm{X} 2$ & $\begin{array}{l}\text { Pernyataan } \\
12\end{array}$ & 0,1986 & 0,462 & Valid \\
\hline $\mathrm{X} 2$ & $\begin{array}{l}\text { Pernyataan } \\
13\end{array}$ & 0,1986 & 0,930 & Valid \\
\hline $\mathrm{X} 2$ & $\begin{array}{l}\text { Pernyataan } \\
14\end{array}$ & 0,1986 & 0,909 & Valid \\
\hline $\mathrm{X} 2$ & $\begin{array}{l}\text { Pernyataan } \\
15\end{array}$ & 0,1986 & 0,890 & Valid \\
\hline $\mathrm{X} 2$ & $\begin{array}{l}\text { Pernyataan } \\
16\end{array}$ & 0,1986 & 0,919 & Valid \\
\hline $\mathrm{X} 2$ & $\begin{array}{l}\text { Pernyataan } \\
17\end{array}$ & 0,1986 & 0,903 & Valid \\
\hline $\mathrm{X} 2$ & $\begin{array}{l}\text { Pernyataan } \\
18\end{array}$ & 0,1986 & 0,869 & Valid \\
\hline $\mathrm{X} 2$ & $\begin{array}{l}\text { Pernyataan } \\
19\end{array}$ & 0,1986 & 0,476 & Valid \\
\hline $\mathrm{X} 2$ & $\begin{array}{l}\text { Pernyataan } \\
20\end{array}$ & 0,1986 & 0,919 & Valid \\
\hline $\mathrm{X} 2$ & $\begin{array}{l}\text { Pernyataan } \\
21\end{array}$ & 0,1986 & 0,899 & Valid \\
\hline X3 & $\begin{array}{l}\text { Pernyataan } \\
1\end{array}$ & 0,1986 & 0,727 & Valid \\
\hline X3 & $\begin{array}{l}\text { Pernyataan } \\
2\end{array}$ & 0,1986 & 0,798 & Valid \\
\hline X3 & $\begin{array}{l}\text { Pernyataan } \\
3\end{array}$ & 0,1986 & 0,510 & Valid \\
\hline X3 & $\begin{array}{l}\text { Pernyataan } \\
4\end{array}$ & 0,1986 & 0,563 & Valid \\
\hline X3 & $\begin{array}{l}\text { Pernyataan } \\
5\end{array}$ & 0,1986 & 0,600 & Valid \\
\hline X3 & $\begin{array}{l}\text { Pernyataan } \\
6\end{array}$ & 0,1986 & 0,681 & Valid \\
\hline X3 & $\begin{array}{l}\text { Pernyataan } \\
7\end{array}$ & 0,1986 & 0,726 & Valid \\
\hline X3 & $\begin{array}{l}\text { Pernyataan } \\
8\end{array}$ & 0,1986 & 0,781 & Valid \\
\hline X3 & $\begin{array}{l}\text { Pernyataan } \\
9\end{array}$ & 0,1986 & 0,710 & Valid \\
\hline X3 & $\begin{array}{l}\text { Pernyataan } \\
10\end{array}$ & 0,1986 & 0,752 & Valid \\
\hline X3 & $\begin{array}{l}\text { Pernyataan } \\
11\end{array}$ & 0,1986 & 0,498 & Valid \\
\hline X3 & $\begin{array}{l}\text { Pernyataan } \\
12 \\
\end{array}$ & 0,1986 & 0,567 & Valid \\
\hline X3 & $\begin{array}{l}\text { Pernyataan } \\
13 \\
\end{array}$ & 0,1986 & 0,594 & Valid \\
\hline X3 & $\begin{array}{l}\text { Pernyataan } \\
14\end{array}$ & 0,1986 & 0,488 & Valid \\
\hline $\mathrm{X} 4$ & $\begin{array}{l}\text { Pernyataan } \\
1\end{array}$ & 0,1986 & 0,742 & Valid \\
\hline $\mathrm{X} 4$ & $\begin{array}{l}\text { Pernyataan } \\
2 \\
\end{array}$ & 0,1986 & 0,753 & Valid \\
\hline $\mathrm{X} 4$ & $\begin{array}{l}\text { Pernyataan } \\
3\end{array}$ & 0,1986 & 0,542 & Valid \\
\hline $\mathrm{X} 4$ & $\begin{array}{l}\text { Pernyataan } \\
4\end{array}$ & 0,1986 & 0,611 & Valid \\
\hline $\mathrm{X} 4$ & $\begin{array}{l}\text { Pernyataan } \\
5 \\
\end{array}$ & 0,1986 & 0,605 & Valid \\
\hline $\mathrm{X} 4$ & $\begin{array}{l}\text { Pernyataan } \\
6\end{array}$ & 0,1986 & 0,706 & Valid \\
\hline $\mathrm{X} 4$ & Pernyataan & 0,1986 & 0,753 & Valid \\
\hline
\end{tabular}

\begin{tabular}{|l|l|c|c|l|}
\hline & 7 & & & \\
\hline X4 & $\begin{array}{l}\text { Pernyataan } \\
8\end{array}$ & 0,1986 & 0,542 & Valid \\
\hline X4 & $\begin{array}{l}\text { Pernyataan } \\
9\end{array}$ & 0,1986 & 0,753 & Valid \\
\hline X4 & $\begin{array}{l}\text { Pernyataan } \\
10\end{array}$ & 0,1986 & 0,524 & Valid \\
\hline X4 & $\begin{array}{l}\text { Pernyataan } \\
11\end{array}$ & 0,1986 & 0,611 & Valid \\
\hline X4 & $\begin{array}{l}\text { Pernyataan } \\
12\end{array}$ & 0,1986 & 0,599 & Valid \\
\hline X4 & $\begin{array}{l}\text { Pernyataan } \\
13\end{array}$ & 0,1986 & 0,753 & Valid \\
\hline X4 & $\begin{array}{l}\text { Pernyataan } \\
14\end{array}$ & 0,1986 & 0,542 & Valid \\
\hline X4 & $\begin{array}{l}\text { Pernyataan } \\
15\end{array}$ & 0,1986 & 0,616 & Valid \\
\hline X4 & $\begin{array}{l}\text { Pernyataan } \\
16\end{array}$ & 0,1986 & 0,605 & Valid \\
\hline
\end{tabular}

Sumber: Data Olahan Peneliti

Pada tabel di atas uji validitas data variabel sumber daya manusia 15 butir pernyataan. Seluruh butir pernyataan dinyatakan valid dan bisa dimasukkan dalam uji reliabilitas, normalitas dan hipotesis. Hasil validitas dikatakan valid jika $r$ hitung $>r$ tabel (Ghozali, 2016). R tabel di dapat dari $\mathrm{df}=\mathrm{N}-2$, maka $\mathrm{df}=98-2=96$, pada $\mathrm{r}$ tabel di kolom 96 di dapat angka 0,1986, maka semua variabel dinyatakan valid._Uji validitas data variabel sistem pengendalian internal pemerintah terdapat 21 butir pernyataan. Seluruh butir pernyataan dinyatakan valid dan bisa dimasukkan dalam uji reliabilitas, normalitas dan hipotesis. Hasil validitas dikatakan valid jika $r$ hitung $>r$ tabel (Ghozali, 2016). $\mathrm{R}$ tabel di dapat dari df $=\mathrm{N}-2$, maka $\mathrm{df}=98-2=96$, pada $r$ tabel di kolom 96 di dapat angka 0,1986, maka semua variabel dinyatakan valid.

Uji validitas data variabel audit keuangan daerah terdapat 14 butir pernyataan. Seluruh butir pernyataan dinyatakan valid dan bisa dimasukkan dalam uji reliabilitas, normalitas dan hipotesis. Hasil validitas dikatakan valid jika $r$ hitung $>r$ tabel (Ghozali, 2016). R tabel di dapat dari $\mathrm{df}=\mathrm{N}-2$, maka $\mathrm{df}=98-2=96$, pada $\mathrm{r}$ tabel di kolom 96 di dapat angka 0,1986, maka semua variabel dinyatakan valid. Uji validitas data variabel kualitas laporan keuangan terdapat 16 butir pernyataan. Seluruh butir pernyataan dinyatakan valid dan bisa dimasukkan dalam uji reliabilitas, normalitas dan hipotesis. Hasil validitas dikatakan valid jika $r$ hitung $>r$ tabel (Ghozali, 2016). $\mathrm{R}$ tabel di dapat dari $\mathrm{df}=\mathrm{N}-2$, 
maka $\mathrm{df}=98-2=96$, pada $\mathrm{r}$ tabel di kolom 96 di dapat angka 0,1986, maka semua variabel dinyatakan valid.

\section{Uji Reliabilitas Data}

Uji reliabilitas digunakan untuk menunjukkan sejauh mana suatu hasil pengukuran relatif konsisten. Untuk mengukur uji reliabilitas dilakukan dengan menggunakan uji statistik Cronbach Alpha (a). Suatu konstruk atau variabel dikatakan reliabel jika memberikan nilai koefisien lebih besar dari pada 0,60 (Ghozali, 2013). Pada tabel 4.10 uji reliabilitas semua variabel dinyatakan reliabel, karena lebih besar dari 0,60. Hasil pengujian reliabilitas data untuk 66 butir pernyataan dapat diliat pada tabel berikut:

\section{Tabel Hasil Uji Reliabilitas}

\begin{tabular}{|l|l|l|}
\hline Variabel & $\begin{array}{l}\text { Cronbach } \\
\text { Alpha }\end{array}$ & Status \\
\hline Sumber Daya Manusia (X1) & 0,929 & Reliabel \\
\hline $\begin{array}{l}\text { Sistem Pengendalian Internal } \\
\text { Pemerintah (X2) }\end{array}$ & 0,977 & Reliabel \\
\hline Audit Keuangan Daerah (X3) & 0,919 & Reliabel \\
\hline $\begin{array}{l}\text { Kualitas Laporan Keuangan } \\
\text { (Y) }\end{array}$ & 0,926 & Reliabel \\
\hline \multicolumn{2}{|c|}{ Sumber: Data Olahan Peneliti }
\end{tabular}

\section{Uji Normalitas}

Hasil pengujian menunjukan bahwa semua nilai signifikansi uji normalitas dengan metode Komolgrof Smirnov diperoleh nilai $0,229>0,05$ yang artinya bahwa data pada tabel di atas menunjukkan distribusi normal. Hal ini menunjukkan bahwa semua variabel yang diuji normal dan dapat dilanjutkan (Ghozali, 2016).

Tabel Hasil Pengujian Normalitas

\begin{tabular}{|l|l|l|}
\hline \multicolumn{2}{|l|}{} & $\begin{array}{l}\text { Unstandardiz } \\
\text { ed Residual }\end{array}$ \\
\hline $\mathrm{N}$ & Mean & 98 \\
\hline \multirow{3}{*}{ Normal Parametersa,b } & $\begin{array}{l}\text { Std. } \\
\text { Deviation }\end{array}$ & 3.0000000 \\
\hline \multirow{3}{*}{ Most Extreme Differences } & Absolute & .105 \\
\cline { 2 - 3 } & Positive & 105 \\
\cline { 2 - 3 } & Negative & -.068 \\
\hline Kolmogorov-Smirnov Z & 1.041 \\
\hline Asymp. Sig. (2-tailed) & 229 \\
\hline \multicolumn{2}{|c|}{ Sumber: Data Olahan Peneliti } & \\
\hline
\end{tabular}

\section{Uji Heterokedastisitas}

Pada tabel berikut ini hasil pengujian heterokedastisitas menunjukkan bahwa hasil signifikansi lebih besar dari 0,05 maka dapat disimpulkan tidak terjadi heterokedastisitas (Ghozali, 2016).

Tabel Uji Glejser

\begin{tabular}{|c|c|c|c|c|c|c|}
\hline \multicolumn{2}{|c|}{ Model } & \multicolumn{2}{|c|}{$\begin{array}{l}\text { Unstandardized } \\
\text { Coefficients }\end{array}$} & \multirow{2}{*}{\begin{tabular}{|l|} 
Standardize \\
d \\
Coefficients \\
Beta
\end{tabular}} & $t$ & \multirow[t]{2}{*}{ Sig. } \\
\hline & & B & $\begin{array}{l}\text { Std. } \\
\text { Error }\end{array}$ & & & \\
\hline \multirow{4}{*}{1} & (Constant) & 7.157 & 1.607 & & 4.454 & .060 \\
\hline & $\begin{array}{l}\text { Sumber } \\
\text { Daya } \\
\text { Manusia }\end{array}$ & -.084 & .047 & -.314 & -1.795 & .076 \\
\hline & \begin{tabular}{|l} 
Sistem \\
Pengendali \\
an Internal
\end{tabular} & -.038 & .020 & -.245 & -1.898 & .061 \\
\hline & \begin{tabular}{|l|} 
Audit \\
Keuangan \\
Daerah
\end{tabular} & .055 & .052 & .183 & 1.058 & .293 \\
\hline
\end{tabular}

Sumber: Data Olahan Peneliti

\section{Uji Multikolinearitas}

Pada tabel di bawah ini terihat bahwa tidak ada variabel yang memiliki VIF besar dari 10 dan nilai tolerance yang lebih kecil dari 10\%. Dapat diartikan bahwa tidak terdapat korelasi antar variabel bebas yang lebih besar dari 95\%. Sehingga kesimpulannya bahwa variabel independen terbebas dari asumsi klasik multikolinearitas karena tidak terdapat multikolinearitas antar variabel bebas dalam model regresi (Ghozali, 2016).

Tabel Hasil Uji Multikolinearitas

\begin{tabular}{|l|l|l|l|}
\hline Model & & Tolerance & VIF \\
\hline $\begin{array}{l}\text { Sumber Daya } \\
\text { Manusia }\end{array}$ & 0,299 & 3.350 \\
\hline $\begin{array}{l}\text { Sistem Pengendalian } \\
\text { Internal Pemerintah }\end{array}$ & & 0,549 & 1.821 \\
\hline $\begin{array}{l}\text { Audit Keuangan } \\
\text { Daerah }\end{array}$ & 0,306 & 3.263 \\
\hline $\begin{array}{l}\text { Sumber: Data Olahan Peneliti } \\
\text { |l }\end{array}$
\end{tabular}

\section{Analisis Regresi Linier Berganda}

\section{Tabel Hasil Analisis Regresi Linier Berganda}

\begin{tabular}{|c|c|c|c|c|c|c|c|c|}
\hline \multirow{2}{*}{\multicolumn{2}{|c|}{ Model }} & \multicolumn{2}{|c|}{$\begin{array}{l}\text { Unstandardi } \\
\text { zed } \\
\text { Coefficients }\end{array}$} & \multirow{2}{*}{\begin{tabular}{|c|} 
Standard \\
ized \\
Coefficie \\
nts \\
Beta \\
\end{tabular}} & \multirow[t]{2}{*}{$\mathrm{t}$} & \multirow[t]{2}{*}{ Sig. } & \multicolumn{2}{|c|}{$\begin{array}{c}\text { Collinearity } \\
\text { Statistics }\end{array}$} \\
\hline & & B & $\begin{array}{c}\text { Std. } \\
\text { Error }\end{array}$ & & & & \begin{tabular}{l|} 
Toler \\
ance
\end{tabular} & VIF \\
\hline & $\begin{array}{c}\text { (Const } \\
\text { ant) }\end{array}$ & 6.803 & 2.557 & & 2.660 & .009 & & \\
\hline 1 & $\begin{array}{l}\text { Sumbe } \\
\text { r Daya } \\
\text { Manusi } \\
\text { a }\end{array}$ & .396 & .075 & .410 & \begin{tabular}{|l|}
5.289 \\
\end{tabular} & .000 & .299 & 3.350 \\
\hline
\end{tabular}




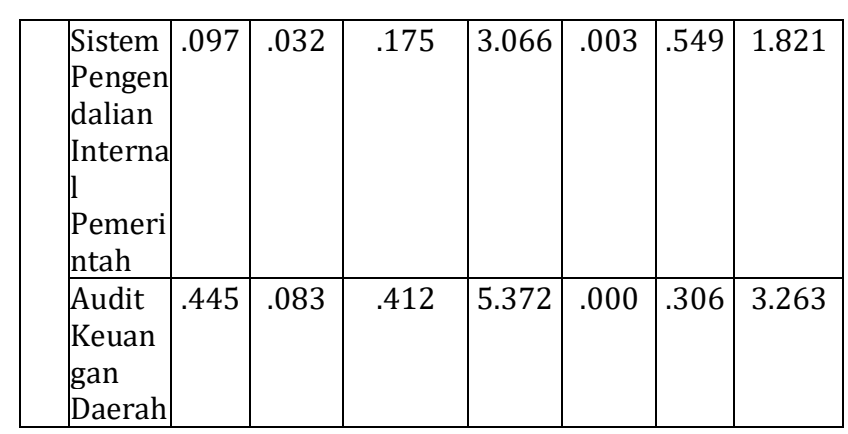

Sumber: Data Olahan Peneliti

\section{Pengaruh Sumber Daya Manusia terhadap Kualitas Laporan Keuangan}

Dari hasil pengujian diperoleh nilai signifikan variabel sumber daya manusia sebesar 0,000 lebih kecil daripada signifikan yang telah ditetapkan yaitu 0,05. Dapat disimpulkan bahwa sumber daya manusia memiliki pengaruh terhadap kualitas laporan keuangan di kantor BPKAD Provinsi Riau. Hasil penelitian ini sejalan dengan penelitian yang dilakukan oleh Triyanti (2017) dan Kuncoro (2017) bahwa sumber daya manusia berpengaruh terhadap kualitas laporan keuangan.

Menurut Undang-Undang Nomor 7 Tahun 2013 mengenai Pedoman Penyusunan Standar Kompetensi Manajerial Pegawai Negeri Sipil, kompetensi adalah karakteristik dan kemampuan kerja yang mencakup aspek pengetahuan, keterampilan dan sikap sesuai tugas dan/atau fungsi jabatan. Kapasitas sumber daya manusia dapat diukur melalui pengetahuan, keterampilan dan perilaku. Sumber daya manusia yang memiliki kualitas yang tinggi akan dapat menunjang kinerja suatu organisasi sehingga dapat mengalami kemajuan. Ketiga hal tersebut yang harus dimiliki dan diperhatikan oleh setiap orang untuk menunjang keberhasilan dalam melaksankan tugas (Hevesi, 2014).

Semakin baik sumber daya manusia di BPKAD Provinsi Riau, maka semakin baik kualitas laporan keuangan yang dihasilkan. Laporan keuangan sebagai output memerlukan sumber daya manusia yang mengimplementasikan, untuk itu diperlukan sumber daya manusia yang kompeten dan memiliki pemahaman yang baik tentang pengelolaan keuangan pemerintah daerah, sehingga akan lebih mudah dalam melaksanakan tugas dan tanggung jawab yang diberikan (Hevesi, 2014). Hal ini juga sejalan dengan teori keagenan, dimana adanya sumber daya manusia yang baik akan memudahkan agent dalam mengkomunikasikan pekerjaan dengan principal sehingga tidak terdapat kesalahpahaman.

\section{Pengaruh Sistem Pengendalian Internal Pemerintah terhadap Kualitas Laporan Keuangan}

Dari hasil pengujian diperoleh nilai signifikan variabel sistem pengendalian internal Pemerintah sebesar 0,003 lebih kecil daripada signifikan yang telah ditetapkan yaitu 0,05. Dapat disimpulkan bahwa sistem pengendalian internal pemerintah mempunyai pengaruh terhadap kualitas laporan keuangan di kantor BPKAD Provinsi Riau. Hasil penelitian ini sejalan dengan penelitian oleh Triyanti (2017) dan Purba (2018) bahwa sistem pengendalian intern berpengaruh terhadap kualitas laporan keuangan.

AICPA menjelaskan bahwa pengendalian internal sangat penting, antara lain untuk memberikan perlindungan bagi entitas terhadap kelemahan manusia serta untuk mengurangi kemungkinan kesalahan dan tindakan yang tidak sesuai dengan aturan. Agar sistem pengendalian internal dapat berfungsi dengan baik maka diperlukan elemen pengendalian internal. Untuk mencapai pengelolaan keuangan negara yang efektif, efisien, transparan, dan akuntabel, wajib dilakukan pengendalian atas penyelenggaraan kegiatan pemerintahan dengan menerapkan elemen-elemen pengendalian internal (COSO, 2013).

Pengendalian Internal merupakan suatu tindakan atau aktivitas yang dilakukan manajemen secara terus menerus untuk memberikan keyakinan yang memadai akan tercapainya tujuan dan sasaran organisasi dan menghindarkan terjadinya kecurangan akuntansi yang dilakukan baik oleh pihak internal maupun eksternal organisasi. Pengendalian internal dapat mengawasi dalam jalannya manajemen sebuah perusahaan, dapat dikatakan bahwa semakin baik sistem pengendalian intern di sebuah perusahaan, maka semakin baik kualitas laporan keuangan yang dihasilkan. Dalam kaitannya dengan teori keagenan, sistem pengendalian internal juga memudahkan 
principal dalam melakukan pengawasan terhadap apa yang dilakukan agent terkait pelaporan keuangan yang berkualitas. Jadi dapat disimpulkan bahwa semakin tinggi sistem pengendalian intern yang diterapkan di kantor BPKAD Provinsi Riau maka kualitas laporan keuangan juga akan semakin meningkat.

\section{Pengaruh Audit Keuangan Daerah terhadap Kualitas Laporan Keuangan}

Dari hasil pengujian diperoleh nilai signifikan variabel audit keuangan daerah sebesar 0,000 lebih kecil dari pada signifikan yang telah ditetapkan yaitu 0,05. Dapat disimpulkan bahwa audit keuangan daerah memiliki pengaruh terhadap kualitas laporan keuangan di kantor BPKAD Provinsi Riau. Hal ini sejalan dengan penelitian dari Sukmandiansyah (2015) yang menyatakan bahwa audit keuangan daerah berpengaruh terhadap kualitas laporan keuangan.

Audit Keuangan Daerah merupakan suatu fungsi penilaian yang bebas dalam suatu organisasi guna menelaah atau mempelajari dan menilai kegiatan-kegiatan perusahaan untuk memberikan saran kepada manajemen. Tujuan audit intern keuangan daerah adalah meneliti dan menilai apakah pelaksanaan daripada sistem pengendalian intern di bidang akuntansi dan operasi cukup dan memenuhi syarat. Menilai disini dimaksudkan menilai apakah kebijakan, rencana dan prosedur yang telah ditentukan betul-betul ditaati, menilai apakah aktiva perusahaan aman dari kehilangan atau kerusakan dan penyelewengan, menilai kecermatan data akuntansi dan data lain dalam organisasi perusahaan, dan menilai mutu atau pelaksanaan daripada tugas-tugas yang diberikan kepada masing-masing manajemen (Sukrisno, 2011).

Adanya kelemahan dalam kualitas laporan keuangan dapat diturunkan dengan meningkatkan keefektifan audit keuangan daerah, jadi dapat disimpulkan bahwa semakin efektif audit keuangan daerah akan meningkatkan kualitas laporan keuangan dikantor BPKAD Provinsi Riau. Hal ini juga sejalan dengan teori keagenan, dengan adanya adanya audit keuangan daerah yang berfungsi sebagai pengawas, mampu menyaring segala penyimpangan-penyimpangan serta ketidakpatuhan terhadap peraturan, sehingga principal dapat mewujudkan laporan keuangan yang berkualitas dan dapat dipertanggungjawabkan.

\section{KESIMPULAN, KETERBATASAN DAN SARAN Kesimpulan}

Berdasarkan pengujian dan

pembahasan dapat disimpulkan hasil penelitian ini adalah: Sumber daya manusia memiliki pengaruh terhadap kualitas laporan keuangan di kantor BPKAD Provinsi Riau, hal ini dikarenakan adanya sumber daya manusia yang kompeten akan menghasilkan kualitas laporan keuangan berkualitas. Sistem pengendalian intern Pemerintah memiliki pengaruh terhadap kualitas laporan keuangan di kantor BPKAD Provinsi Riau, hal ini dikarenakan sistem pengendalian intern pemerintah yang dijalankan sudah cukup baik di kantor tersebut. Audit keuangan daerah memiliki pengaruh terhadap kualitas laporan keuangan di kantor BPKAD Provinsi Riau, hal ini dikarenakan adanya pengawasan yang baik dari audit keuangan daerah dapat mengontrol setiap pengelolaan keuangan yang ada.

\section{Keterbatasan Penelitian}

Beberapa keterbatasan penelitian beserta saran untuk penelitian selanjutnya adalah Ketidakmampuan peneliti untuk menjamin atau mengendalikan sepenuhnya kesungguhan, keterbukaan, serta kejujuran responden dalam memilih opsi jawaban sesuai dengan keadaan dan kenyataan, baik karena ketidakmampuan atau pemahaman yang kurang serta adanya unsur tekanan dari pihak tertentu. Penelitian ini hanya berfokus pada satu instansi saja. Ketidak merataan pengambilan kuesioner.

\section{Saran Penelitian}

Penelitian selanjutnya bisa menggunakan metode wawancara untuk meningkatkan sikap kepedulian dan keseriusan responden dalam menjawab semua pernyataan-pernyataan yang ada. Untuk penelitian selanjutnya dapat dilakukan dengan menambah variabel independen yang lain. Karena sangat memungkinkan variabel independen yang tidak dimasukkan kedalam penelitian ini memiliki pengaruh yang besar terhadap kecurangan akuntansi seperti ketaatan aturan akuntansi, pemanfaatan teknologi informasi dan penerapan good 
corporate governance. Penelitian selanjutnya diharapkan dapat melakukan penelitian di instansi pemerintahan yang lainnya.

\section{DAFTAR PUSTAKA}

Alaihi, Tawakkal. 2017. Analisis Faktor-Faktor Yang Mempengaruhi Keandalan Pelaporan Keuangan Dengan Sistem Pengendalian Intern Pemerintah Sebagai Variabel Moderating Pada Satuan Kerja Perangkat Kabupaten Aceh Timur. Jurnal Repositori Institusi USU.

Agustiawan dan Abdul Halim. 2018. Dimensidimensi Akuntabilitas dan Kineja organisasi sektor Publik. Jurnal Akuntansi dan Ekonomika.Vol. 8. No.1.

Committee of Sponsoring Organizations of the Tradeway Commission (COSO). 2013. Internal Control - Integrated Framework. North Carolina.

Ghozali, I. 2016. Aplikasi Analisis Multivariate dengan Program IBM SPSS 19, Semarang: Badan Penerbit Universitas Diponegoro.

Halim, Abdul. 2012. Akuntansi Sektor Publik: Akuntansi Keuangan Daerah. Edisi Keempat. Jakarta: Salemba Empat

Hevesi, G. Alan. 2014. Standart fir Internal Control in New York State Government. Jakarta.

Ikatan Akuntansi Indonesia. 2016.

Kuncoro, Udi. 2017. Pengaruh Sumber Daya Manusia Dan Penerapan Sistem Informasi Manajemen Daerah (SIMDA) Terhadap Kualitas Laporan Keuangan Pemerintah Daerah. E-Journal Unila.

Mardiasmo. 2009. Akuntansi Sektor Publik . Yogyakarta: Andi Yogyakarta.

Mulyadi. 2014. Sistem Akuntansi. Cetakan Keempat. Jakarta : Salemba Empat.

Nazaruddin dan Syahrial. 2017. Pengaruh Peran Audit Internal Terhadap Kualitas Laporan Keuangan Pemerintah Daerah (Studi Pada Pemerintah Kota Lhokseumawe). Jurnal Akuntansi Dan Pembangunan.

Peraturan Menteri Dalam Negeri Nomor 13 Tahun 2006 tentang Laporan Keuangan Pemerintah Daerah.

Peraturan Pemerintah Nomor 60 Tahun 2008 tentang Sistem Pengendalian Intern Pemerintah.
Peraturan Pemerintah Nomor 71 Tahun 2010 tentang Standar Akuntansi Pemerintah.

Purba, Indria Nurani Br. 2018. Pengaruh Sistem Pengendalian Intern Pemerintah (SPIP) Terhadap Kualitas Laporan Keuangan Pada Kantor Desa Wilayah Kecamatan Sei Suka Kabupaten Batubara. Jurnal Universitas Muhammadiyah Sumatera Utara.

Sukrisno, A. 2011. Auditing Petunjuk Praktis Pemeriksaan Akuntan oleh Akuntan Publik. Salemba Empat: Jakarta.

Sukmadiansyah, Reza. 2015. Pengaruh Penerapan Good Corporate Governance dan Pelaksanaan Audit Internal Terhdap Kualitas Laporan Keuangan. Jurnal Universitas Pasundan.

Syahadatina, Rika dan Fitriyana, Ismiatika. 2016. Pengaruh Sumber Daya Manusia Bidang Keuangan Dan Sistem Pengendalian Internal Terhadap Kualitas Laporan Keuangan Pemerintah Daerah. Aktiva Jurnal Akuntansi dan Investasi.

Triyanti. 2017. Pengaruh Kompetensi Sumber Daya Manusia Di Bidang Akuntansi Dan Sistem Pengendalian Internal Terhadap Kualitas Laporan Keuangan Pemerintah Daerah (Studi Kasus Pada Pemerintah Kabupaten Magelang). Jurnal Universitas Negeri Yogyakarta.

Tugiman. 2016. Standar Profesional Audit Internal. Yogyakarta: Kanisius.

Undang-Undang Nomor 7 Tahun 2013 mengenai Pedoman Penyusunan Standar Kompetensi Manajerial Pegawai Negeri Sipil.

www.pekanbaru.bpk.go.id 